Article

\title{
Electrochemiluminescence Sensor Based on Electrospun Three-Dimensional Carbon Nanofibers for the Detection of Difenidol Hydrochloride
}

\author{
Hao Cheng ${ }^{1,2,+}$, Zhengyuan Zhou ${ }^{1,+}$, Yanqing Li ${ }^{1}$, Wenyi Huang ${ }^{1}$, Jun Feng ${ }^{1}$, Tingfan Tang ${ }^{1}$ \\ and Lijun $\mathrm{Li}^{1,2, *}$ \\ 1 Guangxi Key Laboratory of Green Processing of Sugar Resources, College of Biological and Chemical \\ Engineering, Guangxi University of Science and Technology, Liuzhou 545006, Guangxi, China \\ 2 Province and Ministry Co-Sponsored Collaborative Innovation Center of Sugarcane and Sugar Industry, \\ Nanning 530004, Guangxi, China \\ * Correspondence: gxustllj@163.com \\ + The authors contributed equally.
}

Received: 22 May 2019; Accepted: 16 July 2019; Published: 28 July 2019

\begin{abstract}
The detection of difenidol hydrochloride, which is a drug that is widely used for treating the nausea and vomiting symptoms caused by certain diseases, has been increasingly involved in cases of suicide via overdosing and of drug poisoning in children. A novel electrochemiluminescence (ECL) sensor for the simple and effective detection of difenidol hydrochloride was fabricated by modifying a glassy carbon electrode with three-dimensional carbon nanofibers (3D-CNFs). The 3D-CNFs were synthesized by electrospinning a mixture of montmorillonite (MMT) and polyacrylonitrile, carbonizing the electrospun product, and etching it with hydrofluoric acid. The form and structure of the 3D-CNFs was analyzed via scanning electron microscopy, X-ray photoelectron spectroscopy, and Raman microspectroscopy. According to the experimental results obtained using the modified electrodes, a good linear relationship was found between peak intensity and difenidol concentration $(y=868.14 x$ $\left.-61.04, \mathrm{R}^{2}=0.999\right)$, with a relatively low detection limit $\left(8.64 \times 10^{-10} \mathrm{~mol} \cdot \mathrm{L}^{-1}(\mathrm{~S} / \mathrm{N}=3)\right)$. In addition, our approach exhibited good recovery values ranging from $98.99 \%$ to $102.28 \%$. The proposed novel ECL sensor has wide application prospects for the detection of difenidol hydrochloride.
\end{abstract}

Keywords: carbon nanofiber; difenidol hydrochloride; electrochemiluminescence; $\mathrm{Ru}(\mathrm{bpy})_{3}{ }^{2+}$

\section{Introduction}

Difenidol hydrochloride (1,1-diphenyl-4-piperidino-1-butanol hydrochloride) is used to relieve or prevent dizziness, nausea, and vomiting [1]. Since its first approval in the United States in 1967 [2], this drug has been widely used in China and has contributed to the treatment of labyrinthitis, vestibular neuronitis, and Meniere's disease [3]. It is believed to diminish vestibular stimulation and depress nausea and vomiting at the medullary chemoreceptor trigger zone [4]. Cases of drug poisoning in children and of adults taking the drug to commit suicide have been recently reported. Thus, there is an increasingly urgent need to develop methods for the detection of difenidol hydrochloride. High-performance liquid chromatography (HPLC) [5,6], chromatography-mass spectrometry (LC-MS) [7], post-chemiluminescence [8], anionic surfactant titration [9], and microfluidic chips [10] are common approaches for detecting difenidol hydrochloride. However, these techniques are time-consuming and require complex and expensive instruments, as well as specialized personnel to operate them. In addition, lack of sensitivity is another concern. Therefore, it is necessary to find a more effective, sensitive, and simpler approach for detecting difenidol hydrochloride. 
Electrochemiluminescence (ECL), which is a kind of luminescence produced during electrochemical redox reactions, combines the advantages of chemiluminescence and electrochemistry [11]. It has a wide range of applications [12] owing to the simple equipment required and its high sensitivity [13], rapid detection times, and ease of operation [14-16]. ECL is a field of growing interest and has been widely applied in various areas, including biology [17,18], environmental science [19], and pharmacology $[20,21]$. Tris $\left(2,2^{\prime}\right.$-bipyridyl)ruthenium(II) $\left(\mathrm{Ru}(\mathrm{bpy})_{3}{ }^{2+}\right)$ is one of the most widely used chemiluminescent reagents in ECL systems because of its stability and efficiency [22].

It is possible to chemically modify electrodes to change the microstructure of their surface, and in turn, enhance the sensitivity and selectivity of ECL-based sensing devices. The enhancement of ECL systems through electrode surface modification is expected to extend the research scope of ECL and facilitate its application for drug detection. Electrospun carbon nanofibers (CNFs) have become a promising candidate among potential materials for electrode modification owing to their high surface-area-to-volume ratio [23-25], high strength, excellent electrical conductivity, and high number of edge plane defects on the outer wall, which facilitates electron transfer [26-28].

It has been established in previous studies that ECL and capillary electrophoresiselectrochemiluminescence (CE-ECL) can be used to detect difenidol hydrochloride [29,30]. The working electrodes respectively used for these two approaches are multi-walled carbon nanotube-modified glassy carbon electrodes (MWCNTs/GCEs) and platinum (Pt) electrodes modified with gold nanostructures. However, carbon nanofiber-modified glassy carbon electrodes represent a new kind of sensor that has not been previously reported.

In this study, montmorillonite (MMT) was chosen as a proppant and mixed into an electrospinning precursor solution. After electrospinning, carbonization, and etching with hydrofluoric acid (HF), three-dimensional (3D) networks of carbon nanofibers (3D-CNFs) were obtained. These kinds of 3D networks contain numerous active sites, which accelerate electron transfer. After modifying the surface of a glassy carbon electrode (GCE) using these 3D networks, an ECL sensor capable of difenidol hydrochloride detection was obtained. Scheme 1 shows the fabrication process of the glassy carbon electrode modified by three-dimensional networks of carbon nanofibers (3D-CNF/GCE) and the detection procedure for difenidol.

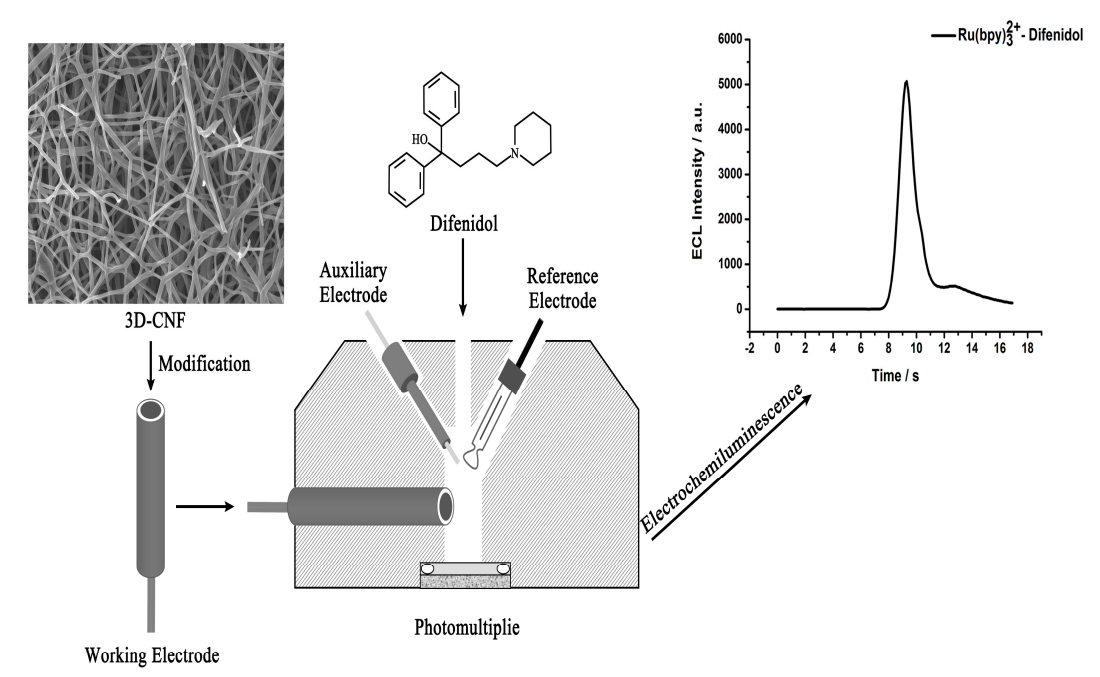

Scheme 1. Preparation of the three-dimensional networks of carbon nanofibers (3D-CNF/GCE) and the detection process for difenidol. 


\section{Experiments}

\subsection{Reagents}

A standard stock solution with a concentration of $1.5 \times 10^{-3} \mathrm{~mol} / \mathrm{L}$ of difenidol hydrochloride was prepared by dissolving difenidol hydrochloride (National Institutes for Food and Drug Control (NIFDC), Beijing, China) into ultrapure water and was stored in a refrigerator. A stock solution of $\mathrm{Ru}(\mathrm{bpy})_{3}{ }^{2+}$ was prepared by dissolving $\mathrm{Ru}(\mathrm{bpy})_{3} \mathrm{Cl}_{2} \cdot 6 \mathrm{H}_{2} \mathrm{O}$ in ultrapure water. Polyacrylonitrile (PAN; molecular weight: $85,000 \mathrm{~g} / \mathrm{mol}$, Sigma-Aldrich Co., Ltd. Shanghai, China) was used as the carbon source for the nanofibers. $N, N$-dimethylformamide (DMF), acetone, and Nafion solutions (5 wt.\%) were purchased from Sigma-Aldrich (Shanghai, China). All the chemicals used in the experiments were of analytical grade, and ultrapure water was used. A 0.1-M borate buffer solution $(\mathrm{pH}=7.5)$ was prepared by mixing a $0.1-\mathrm{M} \mathrm{H}_{3} \mathrm{BO}_{3}$ solution and $\mathrm{Na}_{2} \mathrm{~B}_{4} \mathrm{O}_{7} \cdot 10 \mathrm{H}_{2} \mathrm{O}$ solution.

\subsection{Instruments}

Field-emission scanning electron microscope (FE-SEM; CarlZeiss, Germany) was used to observe the external morphology of the synthesized materials. An X-ray photoelectron spectroscope (XPS, Kratos Analytical Ltd., UK) was used to determine the elemental composition of the materials' surface layer. A laser confocal Raman microspectroscope (Raman, XploRA PLUS, Horiba) was used to measure the Raman spectra of the materials.

\subsection{Synthesis of CNFs}

The precursor solution for the electrospinning process was prepared as follows: $1.6 \mathrm{~g}$ of PAN powder and 15-wt.\% MMT were dissolved in $10 \mathrm{~mL}$ of DMF via magnetic stirring for approximately $12 \mathrm{~h}$ at room temperature. As a result, a solution of PAN/MMT composites was obtained. The electrospinning process, which results in nanofiber formation, was carried out by applying a high voltage of $15 \mathrm{kV}$. After drying in a vacuum for $12 \mathrm{~h}$, the composite nanofibers were calcinated in $\mathrm{N}_{2}$ at $800{ }^{\circ} \mathrm{C}$ at a heating rate of $2{ }^{\circ} \mathrm{C} / \mathrm{min}$. They were then left to naturally cool down to room temperature. Subsequently, the composite nanofibers were etched with $10 \% \mathrm{HF}$ and rinsed with deionized water until a neutral $\mathrm{pH}$ was reached. After drying at $80{ }^{\circ} \mathrm{C}$ overnight, the final product was obtained.

\subsection{Fabrication of CNFs/GCEs}

Prior to the fabrication of the final electrode, the GCE was polished until it became a mirror-like surface using fine emery papers and 0.3- and 0.05- $\mu \mathrm{m}$ alumina slurry. Afterwards, the GCE was cleaned ultrasonically using deionized water and ethanol alternatively, and then dried in a $\mathrm{N}_{2}$ atmosphere. Subsequently, $1.5 \mathrm{mg}$ of CNFs were dispersed via sonication in isopropanol- $\mathrm{H}_{2} \mathrm{O}(1: 4, v / v)$ to produce a homogeneous and stable suspension. Then, $5 \mu \mathrm{L}$ of the prepared suspension were pipetted onto to the polished surface of the GCE, followed by drying at room temperature. Through this process, the modified GCE was obtained.

\subsection{Electrochemical and Electrochemiluminescence Measurements}

In this study, all electrochemical (EC) and ECL measurements were performed using a MPI-E electrogenerated chemiluminescence analyzer (Xi'an Remex (Ruimai) Analysis Instruments Co., Ltd., Xi'an, China) with a three-electrode cell. The working electrode was a GCE ( $\Phi=3 \mathrm{~mm})$, the counter electrode was a $\mathrm{Pt}$ wire, and the reference electrode was made of $\mathrm{Ag} / \mathrm{AgCl}$. Cyclic voltammetry (CV) measurements were carried out to determine the EC and ECL properties of difenidol hydrochloride. The sample was put in a borate buffer solution $(0.1 \mathrm{M}, \mathrm{pH}=7.5)$ under optimal conditions; a high negative voltage of $-800 \mathrm{~V}$ was applied to the photomultiplier, the scan rate was $100 \mathrm{mV} / \mathrm{s}$, and the concentration of $\mathrm{Ru}(\mathrm{bpy})_{3}{ }^{2+}$ was $4 \times 10^{-4} \mathrm{M}$. 


\section{Results and Discussion}

\subsection{Drug Substance Characterization}

As shown in Figure 1a,b, the morphological differences between CNFs and 3D-CNFs can be observed via scanning electron microscopy. The CNFs exhibited a planar reticular structure before the addition of MMT. After MMT was added, the substances formed a well-defined and interconnected 3D porous network. Such interconnected networks can facilitate the detection of difenidol hydrochloride because they contain a high number of active sites, which accelerates diffusion [31].
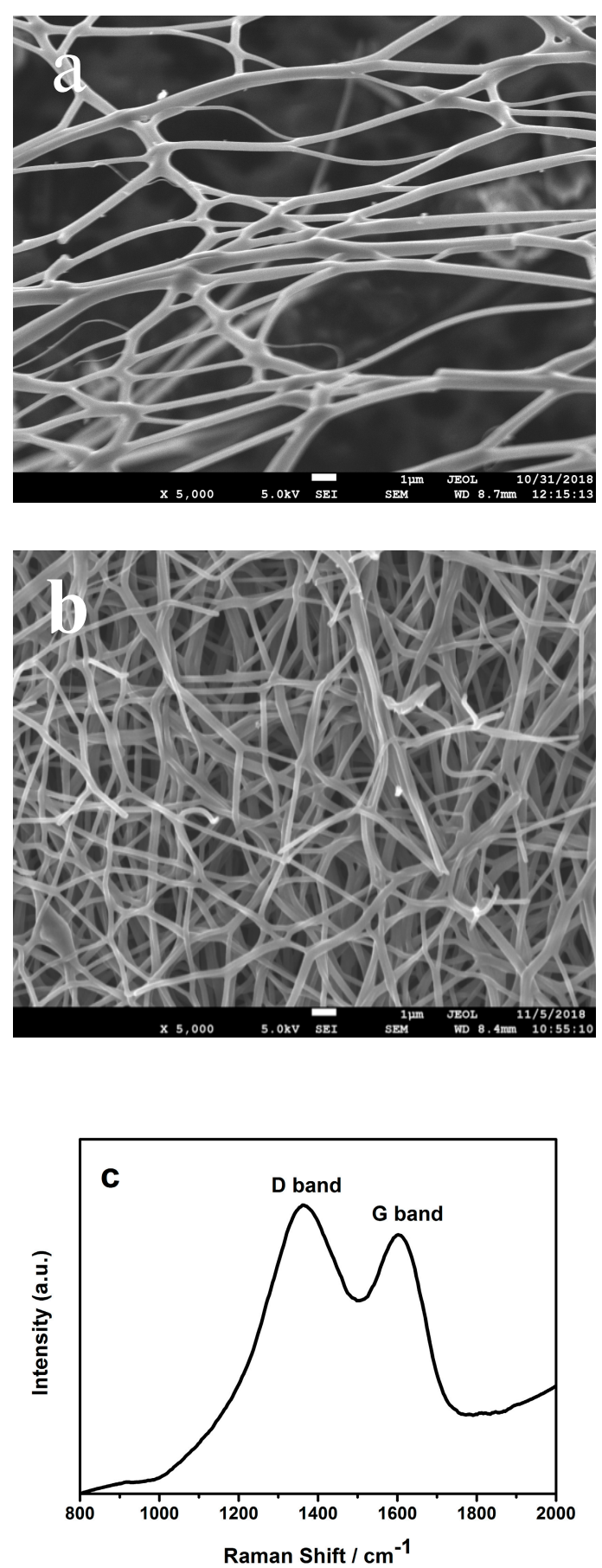

Figure 1. SEM images of carbon nanofibers (CNFs) (a) and 3D-CNFs (b) and Raman spectra of 3D-CNFs (c). 

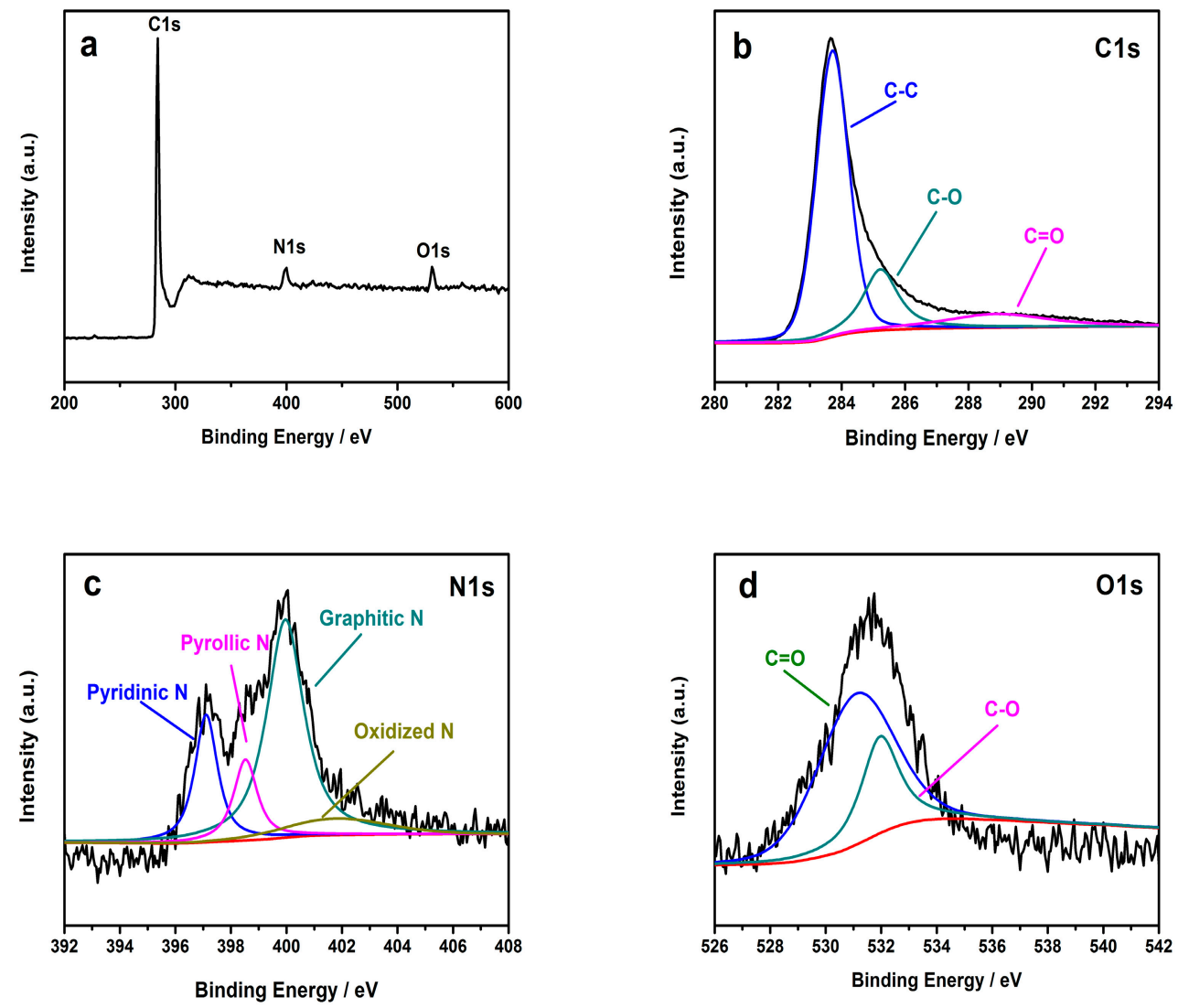

Figure 2. XPS spectra of 3D-CNFs (a) and high-resolution XPS spectra for C1s (b), N1s (c), and O1s (d).

The elemental composition of the sample surface was determined via X-ray photoelectron spectroscopy. The results are presented in Figure 2. According to the XPS spectrum of the sample (Figure 2a), the peaks that appeared at $284.8 \mathrm{eV}, 399 \mathrm{eV}$, and $532 \mathrm{eV}$ can be assigned to C1s (89.51 at.\%), N1s (5.43 at.\%), and O1s (3.24 at.\%), respectively [32]. The deconvoluted high-resolution C1s spectrum (Figure 2b) revealed the presence of three peaks at $284.5 \mathrm{eV}, 285.8 \mathrm{eV}$, and $289 \mathrm{eV}$, which were attributed to $\mathrm{C}=\mathrm{C}, \mathrm{C}-\mathrm{C}$, and $\mathrm{C}=\mathrm{O}$, respectively $[33,34]$. The deconvoluted high-resolution N1s spectrum (Figure 2c) revealed four main peaks at $398.5 \mathrm{eV}, 399.9 \mathrm{eV}, 401.5 \mathrm{eV}$, and $402 \mathrm{eV}$, which were attributed to different types of nitrogen: pyridine, pyrrolic, graphitic, and oxidized nitrogen, respectively $[35,36]$. As shown in Figure 2d, O1s peaks of high intensity were observed at $531.8 \mathrm{eV}$ and $533 \mathrm{eV}$, which were attributed to $\mathrm{C}=\mathrm{O}$ and $\mathrm{C}-\mathrm{O}$, respectively [37].

Raman spectroscopy was performed to obtain detailed information about the chemical structure of the sample. The disorder-induced D band (graphite) and the order-induced G band (graphite) were observed in the measured Raman spectrum. As shown in Figure 1c, the D band and the G band appeared at 1380 and $1600 \mathrm{~cm}^{-1}$, respectively [38,39]. The relative intensity of the $\mathrm{D}$ and $\mathrm{G}$ bands $\left(\mathrm{I}_{\mathrm{D}} / \mathrm{I}_{\mathrm{G}}\right)$ was 1.05, indicating a low degree of graphitization and a high degree of disorder in the sample [40,41].

\subsection{EC and ECL Behaviors of Difenidol Hydrochloride}

\subsubsection{ECL Behavior of Difenidol Hydrochloride on 3D-CNFs-Modified GCEs}

As shown in Figure 3, when trying to detect difenidol hydrochloride using the 3D-CNFs/GCE without $\mathrm{Ru}(\mathrm{bpy})_{3}{ }^{2+}$, no significant electrochemical response was observed. This proves that difenidol hydrochloride has poor ECL properties. 


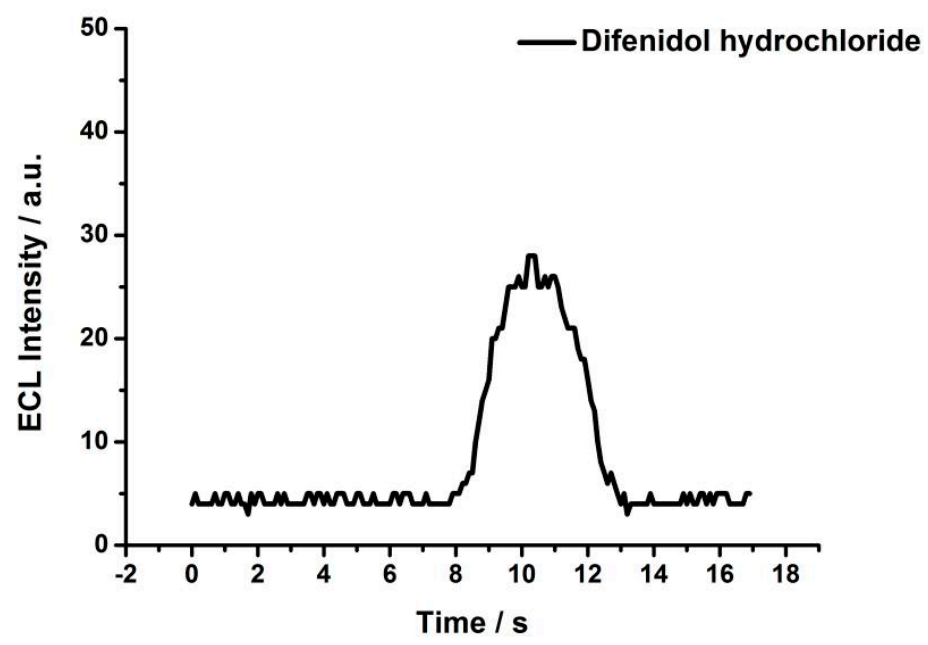

Figure 3. ECL intensity-time curve of difenidol hydrochloride in a solution with $3 \times 10^{-5} \mathrm{~mol} \cdot \mathrm{L}^{-1}$ of difenidol and $0.1 \mathrm{~mol} \cdot \mathrm{L}^{-1}$ of BBS ( $\left.\mathrm{pH} 7.5\right)$.

3.2.2. EC and ECL Behaviors of $\mathrm{Ru}(\mathrm{bpy})_{3}{ }^{2+}$ and $\mathrm{Ru}(\mathrm{bpy})_{3}{ }^{2+}$-Difenidol Hydrochloride on 3D-CNFs-Modified GCEs

As shown in Figure $4 \mathrm{a}$, the oxidation peak was identified at $+1.0 \mathrm{~V}$ and increased when difenidol hydrochloride was added to the electrolyte solution. This was due to the synergetic effect of difenidol hydrochloride on the oxidation-reduction reactions of $\mathrm{Ru}(\mathrm{bpy})_{3}{ }^{2+}$ [42], by which the tertiary amino of difenidol was oxidized into radical cations.
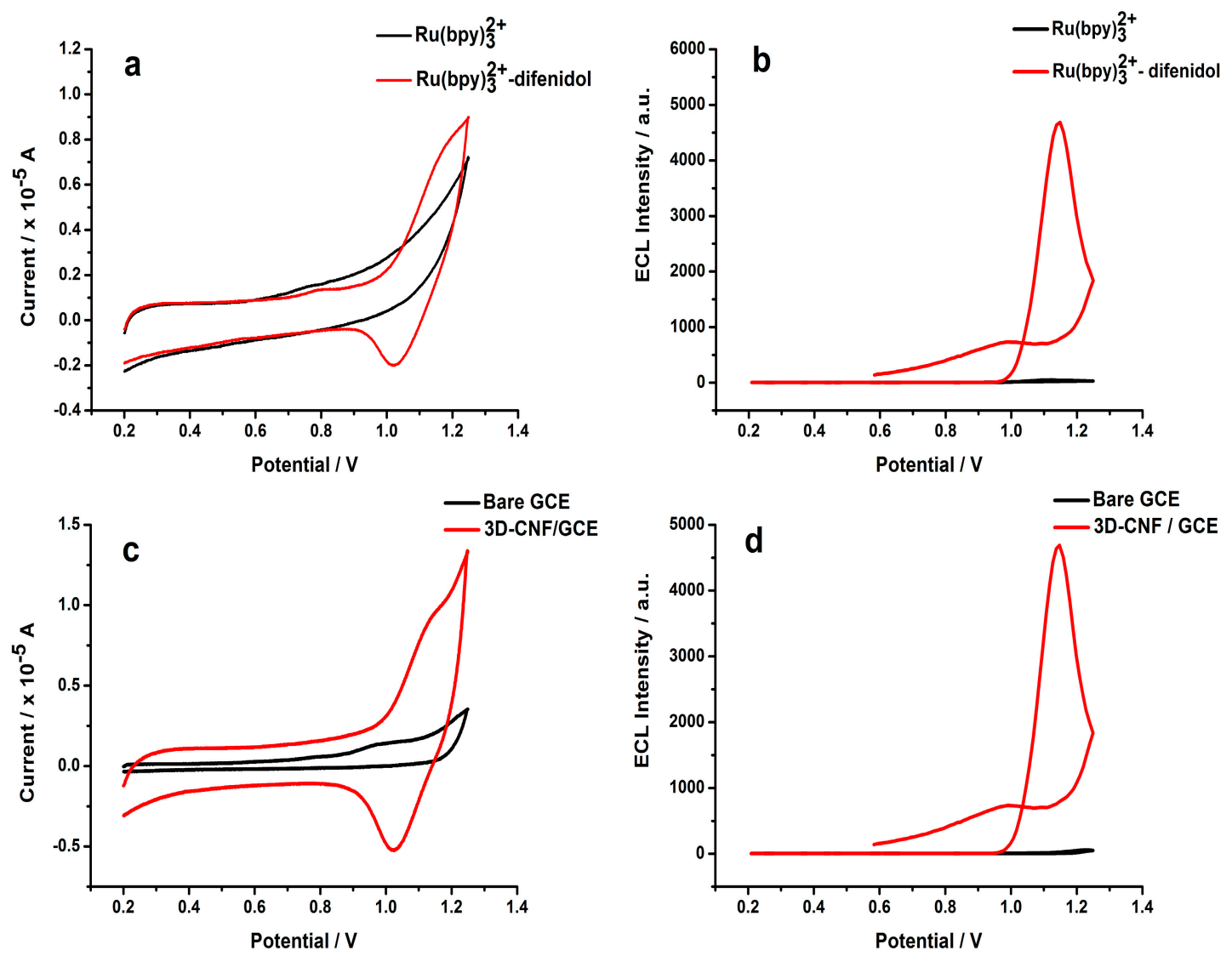

Figure 4. EC (a) and ECL (b) curves of $\mathrm{Ru}(\mathrm{bpy})_{3}{ }^{2+}$ and $\mathrm{Ru}(\mathrm{bpy})_{3}{ }^{2+}$-difenidol hydrochloride in a 0.1-mol. $\mathrm{L}^{-1}$ borate buffer solution ( $\mathrm{pH} 7.5$ ), and EC (c) and ECL (d) curves of Ru(bpy) ${ }^{2+}$-difenidol hydrochloride in a $0.1-\mathrm{mol} \cdot \mathrm{L}^{-1}$ BBS solution $(\mathrm{pH} 7.5)$ on a bare GCE and a 3D-CNF GCE, respectively. 
ECL was generated via annihilation. The ECL response of $\mathrm{Ru}(\mathrm{bpy})_{3}{ }^{2+}$ was measured and found to be weak; the results are shown in Figure $4 \mathrm{~b}$. The corresponding ECL mechanism is shown in Equations (1)-(4). In contrast, when difenidol was added, ECL intensity was greatly enhanced. This occurred because difenidol not only transfers electrons to the surface of the electrodes, but also produces highly reducible intermediates with great energy, such as free radicals. This mechanism can be expressed as Equations (5)-(11) [43-46].

$$
\begin{aligned}
& \mathrm{Ru}(\mathrm{bpy})_{3}{ }^{2+}-\mathrm{e}^{-} \rightarrow \mathrm{Ru}(\mathrm{bpy})_{3}{ }^{3+} \\
& \mathrm{Ru}(\mathrm{bpy})_{3}{ }^{2+}+\mathrm{e}^{-} \rightarrow \mathrm{Ru}(\mathrm{bpy})_{3}{ }^{+} \\
& \mathrm{Ru}(\mathrm{bpy})_{3}{ }^{3+}+\mathrm{Ru}(\mathrm{bpy})_{3}{ }^{+} \rightarrow \mathrm{Ru}(\mathrm{bpy})_{3}{ }^{2+}+\mathrm{Ru}(\mathrm{bpy})_{3}{ }^{2+*} \\
& \mathrm{Ru}(\mathrm{bpy})_{3}{ }^{2+^{*}} \rightarrow \mathrm{Ru}(\mathrm{bpy})_{3}{ }^{2+}+h v \\
& \mathrm{C}_{20} \mathrm{H}_{24} \mathrm{OCH}_{3} \mathrm{~N}-\mathrm{e}^{-} \rightarrow \mathrm{C}_{20} \mathrm{H}_{24} \mathrm{OCH}_{3} \mathrm{~N}^{+} \\
& \mathrm{C}_{20} \mathrm{H}_{24} \mathrm{OCH}_{3} \mathrm{~N}^{+} \rightarrow \mathrm{C}_{20} \mathrm{H}_{24} \mathrm{ONC}^{*} \mathrm{H}_{2}+\mathrm{H}^{+} \\
& \mathrm{Ru}(\mathrm{bpy})_{3}{ }^{2+}-\mathrm{e}^{-} \rightarrow \mathrm{Ru}(\mathrm{bpy})_{3}{ }^{3+} \\
& \mathrm{C}_{20} \mathrm{H}_{24} \mathrm{ONC}^{*} \mathrm{H}_{2}+\mathrm{Ru}(\text { bpy })_{3}{ }^{3+} \rightarrow \mathrm{Ru}(\text { bpy })_{3}{ }^{2+*}+\mathrm{C}_{20} \mathrm{H}_{24} \mathrm{ON}^{+}=\mathrm{CH}_{2} \\
& \mathrm{C}_{20} \mathrm{H}_{24} \mathrm{ONC}^{*} \mathrm{H}_{2}+\mathrm{Ru}(\text { bpy })_{3}{ }^{2+} \rightarrow \mathrm{Ru}(\text { bpy })_{3}{ }^{+} \\
& \mathrm{Ru}(\mathrm{bpy})_{3}{ }^{3+}+\mathrm{Ru}(\mathrm{bpy})_{3}{ }^{+} \rightarrow \mathrm{Ru}(\mathrm{bpy})_{3}{ }^{2+*} \\
& \mathrm{Ru}(\mathrm{bpy})_{3}{ }^{2+*} \rightarrow \mathrm{Ru}(\mathrm{bpy})_{3}{ }^{2+}+h v
\end{aligned}
$$

\subsubsection{EC and ECL Behaviors of $\mathrm{Ru}(\mathrm{bpy})_{3}{ }^{2+}$-Difenidol Hydrochloride}

Figure $4 c$, d shows the EC and ECL curves of Ru(bpy) ${ }_{3}{ }^{2+}$-difenidol on bare GCEs and 3D/CNF GCEs, respectively. It can be observed that both the chemical current and ECL intensity of $\mathrm{Ru}(\mathrm{bpy})_{3}{ }^{2+}$-difenidol on the modified electrodes were higher than that on the bare electrodes. Moreover, the ECL intensity of $\mathrm{Ru}(\mathrm{bpy})_{3}{ }^{2+}$-difenidol on the modified electrodes was approximately 60 times higher than that on the bare electrodes. This is because the 3D-CNFs have a large surface area and many edge plane defects on their outer wall, which enhances the diffusion of difenidol and provides an efficient pathway for electron transfers. Consequently, the charge transfer rate increases.

\subsubsection{Diffusion Coefficient of Difenidol on Different Electrodes}

To prove that 3D-CNFs can accelerate the diffusion of difenidol, and thereby contribute to enhancing the resulting ECL signal, the diffusion of difenidol on different electrodes was studied via chronoamperometry. The diffusion coefficients of difenidol on the different electrodes were calculated according to the Cottrell equation. As shown in Table 1, the diffusion coefficient of difenidol on the 3D-CNF/GCE was higher than that on the bare GCE, which is consistent with the fact that the ECL intensity of difenidol on the 3D-CNF/GCEs was greater than that on the bare electrodes. This indicates that 3D-CNFs can enhance the diffusion of difenidol.

Table 1. Diffusion coefficient of difenidol on different electrodes.

\begin{tabular}{cccc}
\hline Electrodes & Regression Equation & $\mathbf{R}^{\mathbf{2}}$ & Diffusion Coefficient $\left(\mathbf{c m}^{2} / \mathbf{s}\right)$ \\
\hline Bare GCE & $I=-4.224 \times 10^{-8}+3.104 \times 10^{-7} \mathrm{t}^{-1 / 2}$ & 0.993 & $1.464 \times 10^{-10}$ \\
3D-CNF GCE & $I=-1.238 \times 10^{-6}+4.053 \times 10^{-6} \mathrm{t}^{-1 / 2}$ & 0.997 & $2.496 \times 10^{-8}$ \\
\hline
\end{tabular}




\subsection{Optimization of Detection Conditions}

After preparing various sensors, we optimized several influencing factors to obtain the best sensitivity for the detection of difenidol hydrochloride. These factors included buffer type and $\mathrm{pH}$ value, the volume of 3D-CNFs used for surface modification, the concentration of $\mathrm{Ru}(\mathrm{bpy})_{3}{ }^{2+}$, the scan rate, and the high negative voltage applied.

\subsubsection{Effects of 3D-CNFs Modification}

As shown in Figure 5a, the light signal increased with the volume of 3D-CNFs within the range of 2 to $4 \mu \mathrm{L}$. This could be ascribed to the resulting larger surface area and higher number of active sites. For volumes higher than $4 \mu \mathrm{L}$, the light signal begins to decrease as the volume increases. This is because excessively thick modification hinders electron transport [47]. Thus, $4 \mu \mathrm{L}$ was chosen as the optimal volume of 3D-CNFs for surface modification.


Figure 5. Optimization of detection conditions: (a) volume of 3D-CNFs; (b) buffer type and pH value. A 0.1-M BBS solution was used $\left(\mathrm{pH}=7.5\right.$; with a concentration of $3 \times 10^{-5} \mathrm{~mol} \cdot \mathrm{L}^{-1}$ of difenidol hydrochloride). Error bar: standard deviation for $n=3$. PBS:phosphate buffer solution; BBS: borate buffer solution.

\subsubsection{Effects of Buffer Type and $\mathrm{pH}$ Value}

The buffer type and $\mathrm{pH}$ value used will greatly determine the stability and signal strength in ECL-based detection systems [48]. Thus, selecting the best buffer solution is vital for the detection of difenidol. The effects of using a phosphate buffer solution (PBS) and a borate buffer solution (BBS) were analyzed. In these experiments, each buffer was designed to contain $3 \times 10^{-5} \mathrm{~mol} \cdot \mathrm{L}^{-1}$ of difenidol hydrochloride. Figure $5 \mathrm{~b}$ shows the comparative ECL intensities obtained, where it can be seen that BBS exhibited the best performance. The maximum ECL intensity was achieved at a $\mathrm{pH}$ of 7.5, because the use of a high $\mathrm{pH}$ value helped in the deprotonation of difenidol, and thus enhanced the luminescence signal [42]. Therefore, in subsequent experiments, we adopted BBS as the buffer solution and used it at an optimal $\mathrm{pH}$ of 7.5 .

\subsubsection{Effects of the Concentration of $\mathrm{Ru}(\mathrm{bpy})_{3}{ }^{2+}$}

We hypothesized that the concentration of the luminescent reagent would also affect the ECL intensity of $\mathrm{Ru}(\mathrm{bpy}) 3_{3}{ }^{2+}$-difenidol. According the experimental data obtained, ECL intensity reached its maximum value when the concentration of $\mathrm{Ru}(\mathrm{bpy})_{3}{ }^{2+}$ was $4 \times 10^{-4} \mathrm{~mol} \cdot \mathrm{L}^{-1}$, and then fell off as the concentration of $\mathrm{Ru}(\mathrm{bpy})_{3}{ }^{2+}$ continued to increase. The other influencing factors were controlled; difenidol hydrochloride was used at a concentration of $3 \times 10^{-5} \mathrm{~mol} \cdot \mathrm{L}^{-1}$ in BBS at a $\mathrm{pH}$ of 7.5. Therefore, our initial hypothesis was verified. Considering the resulting signal-to-noise ratio (SNR), an optimal concentration of $\mathrm{Ru}(\mathrm{bpy})_{3}{ }^{2+}$ of $4 \times 10^{-4} \mathrm{~mol} \cdot \mathrm{L}^{-1}$ was chosen. 


\subsubsection{Selection of Instrument Parameters}

To increase the service life of the photomultiplier and ensure the stability and sensitivity of the detection system, the effects of varying the high negative voltage applied and the scanning rate were studied. The other influencing factors were controlled; the $\mathrm{pH}$ of the BBS was maintained at 7.5 and difenidol hydrochloride was used at a concentration of $3 \times 10^{-5} \mathrm{~mol} \cdot \mathrm{L}^{-1}$. We found that when the negative high voltage applied was $-800 \mathrm{~V}$ and the scanning rate was $0.1 \mathrm{~V} \cdot \mathrm{s}^{-1}$, the measured signal was stable but with a lower SNR. Because the use of a higher scan rate would negatively affect the instrument [12], the aforementioned values were selected as the optimal instrument parameters.

\subsection{Analytical Performance of the 3D-CNFs/GCEs}

Using the optimal conditions stated above, the ECL intensities for different concentrations of difenidol hydrochloride on the 3D-CNFs-modified GCEs were studied using an MPI-E electrogenerated chemiluminescence analyzer. Figure $6 \mathrm{a}$ shows that the peak current increased gradually as the concentration of difenidol hydrochloride increased, and there was a good linear relationship between peak intensity and the concentration of difenidol hydrochloride within the range of $3 \times 10^{-8}$ to $2 \times 10^{-5} \mathrm{~mol} \cdot \mathrm{L}^{-1}$. The correlation of these two variables followed $\mathrm{y}=868.86 \mathrm{x}+61.04, \mathrm{R}^{2}=0.999$ (Figure $6 \mathrm{~b}$ ), with a detection limit (LOD) of $8.64 \times 10^{-10} \mathrm{~mol} \cdot \mathrm{L}^{-1}(\mathrm{~S} / \mathrm{N}=3)$. Table 2 shows that the proposed ECL sensor based on a 3D-CNF-modified GCE had a higher sensitivity and stronger linear relationship for the detection of difenidol hydrochloride than traditional methods. Additionally, it also had a lower LOD than other approaches.
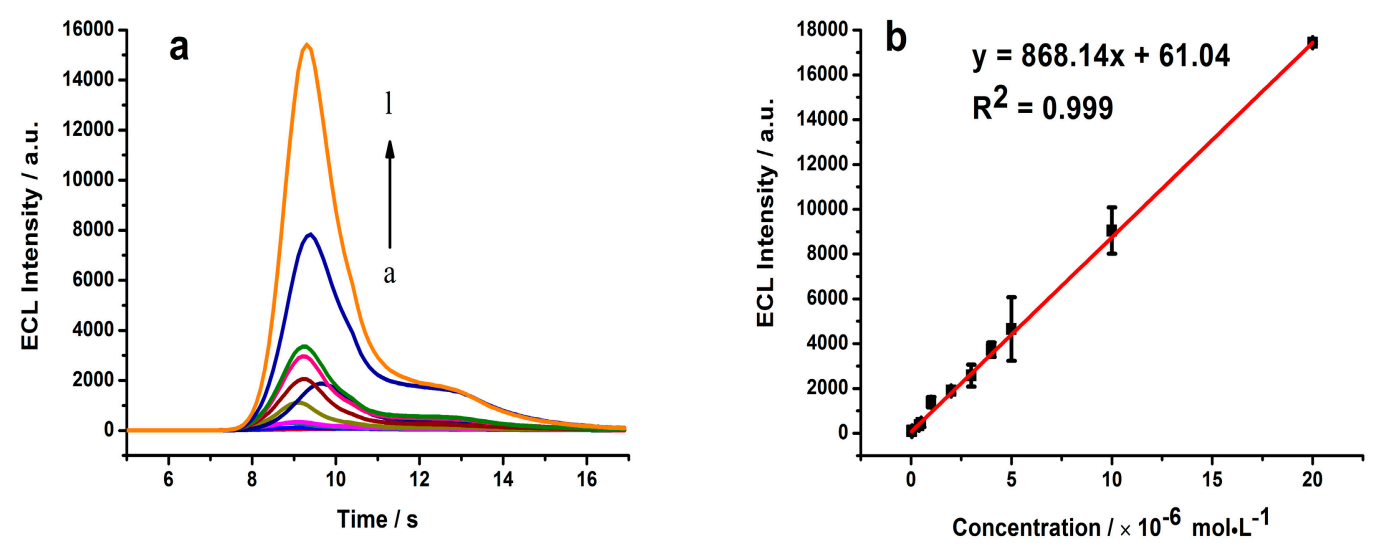

Figure 6. ECL responses of the $3 \mathrm{D}-\mathrm{CNF} / \mathrm{GCE}$ in a $0.1-\mathrm{M}$ borate buffer solution (a) for different concentrations of difenidol hydrochloride ranging from $3 \times 10^{-8}$ to $2 \times 10^{-5} \mathrm{~mol} \cdot \mathrm{L}^{-1}$; (b) calibration curves of the ECL responses for different difenidol hydrochloride concentrations. Error bar: standard deviation for $\mathrm{n}=3$.

Table 2. Comparison of different methods used for the detection of difenidol hydrochloride.

\begin{tabular}{cccc}
\hline Methods & Linear Range $\left(\mathbf{m o l} \cdot \mathbf{L}^{-\mathbf{1})}\right.$ & $\begin{array}{c}\text { Detection Limit } \\
\left(\mathbf{m o l} \cdot \mathbf{L}^{-\mathbf{1}} \mathbf{)}\right.\end{array}$ & References \\
\hline HPLC & $3.58 \times 10^{-5}-1.08 \times 10^{-4}$ & - & {$[5]$} \\
LC-MS/MS & $2.89 \times 10^{-9}-2.89 \times 10^{-7}$ & $1.45 \times 10^{-9}$ & {$[7]$} \\
Post-chemiluminescence & $1.73 \times 10^{-8}-2.89 \times 10^{-7}$ & $5.78 \times 10^{-9}$ & {$[8]$} \\
CE-ECL & $1.00 \times 10^{-6}-6.00 \times 10^{-5}$ & $1.00 \times 10^{-7}$ & {$[29]$} \\
ECL & $1.00 \times 10^{-6}-3.30 \times 10^{-5}$ & $5.00 \times 10^{-7}$ & {$[30]$} \\
ECL & $1.00 \times 10^{-7}-1.00 \times 10^{-4}$ & $6.49 \times 10^{-10}$ & {$[42]$} \\
ECL & $3.00 \times 10^{-8}-2.00 \times 10^{-5}$ & $8.64 \times 10^{-10}$ & This work \\
\hline
\end{tabular}

HPLC: high-performance liquid chromatography, LC-MS/MS: liquid chromatography-mass spectrometry, CE: capillary electrophoresis. 


\subsection{Selectivity of the Sensor}

An interference study was carried out under the aforementioned optimal conditions. We aimed to analyze the selectivity of the ECL sensor for detecting $1.0 \times 10^{-5} \mathrm{~mol} \cdot \mathrm{L}^{-1}$ of difenidol hydrochloride. We found that concentrations of $\mathrm{Na}^{+}, \mathrm{K}^{+}, \mathrm{Cl}^{-}$, and $\mathrm{NO}_{3}{ }^{-} 500$ times higher, of glucose, sucrose, and fructose 25 times higher, and of ascorbic acid 5 times higher did not interfere with the detection of difenidol hydrochloride.

\subsection{Reproducibility and Repeatability of the Modified Electrodes}

Five different 3D-CNFs-modified electrodes were prepared to detect difenidol hydrochloride. The results indicated good reproducibility with a relative standard deviation (RSD) of 3.40\%. Similarly, the same modified electrode was used repeatedly ten times and its RSD was 3.75\%. In other words, 3D-CNF/GCEs have the advantages of both good repeatability and reproducibility.

\subsection{Analysis of a Real Sample}

A solution with a concentration of $1.5 \times 10^{-6} \mathrm{~mol} \cdot \mathrm{L}^{-1}$ of difenidol hydrochloride was obtained by dissolving five crushed tablets of difenidol hydrochloride in deionized water. Appropriate parts of the solution were taken as samples, which were accurately weighed using an analytical balance. Subsequently, the 3D-CNFs/GCE sensor was used for the detection of difenidol hydrochloride in the sample solutions under the optimal conditions. Additional experiments were also carried out as standards. Table 3 shows that the recoveries ranged from $98.99 \%$ to $102.28 \%$, demonstrating the good performance of the proposed sensors in practical applications.

Table 3. Detection of difenidol hydrochloride in real samples and their recoveries.

\begin{tabular}{|c|c|c|c|c|c|}
\hline $\begin{array}{c}\text { Sample } \\
\left(\times 10^{-6} \mathrm{~mol} \cdot \mathrm{L}^{-1}\right)\end{array}$ & $\begin{array}{c}\text { Added } \\
\left(\times 10^{-6} \mathrm{~mol} \cdot \mathrm{L}^{-1}\right)\end{array}$ & $\begin{array}{c}\text { Actual } \\
\left(\times 10^{-6} \mathrm{~mol} \cdot \mathrm{L}^{-1}\right)\end{array}$ & $\begin{array}{c}\text { Founded } \\
\left(\times 10^{-6} \mathrm{~mol} \cdot \mathrm{L}^{-1}\right)\end{array}$ & $\begin{array}{c}\text { Recovery } \\
(\%)\end{array}$ & $\begin{array}{c}\text { R.S.D. } \\
(\%, n=3)\end{array}$ \\
\hline 0 & - & - & - & - & - \\
\hline \multirow{5}{*}{1.5} & 1.5 & 0.75 & $0.74 \pm 0.03$ & 99.10 & 3.91 \\
\hline & 3 & 1.125 & $1.15 \pm 0.02$ & 102.28 & 1.77 \\
\hline & 6 & 1.875 & $1.86 \pm 0.02$ & 99.51 & 1.02 \\
\hline & 15 & 4.125 & $4.12 \pm 0.20$ & 101.10 & 4.41 \\
\hline & 30 & 7.875 & $7.83 \pm 0.20$ & 98.99 & 1.97 \\
\hline
\end{tabular}

R.S.D.: relative standard deviation.

\section{Conclusions}

In this study, an ECL sensor was produced by modifying the surface of a glassy carbon electrode with 3D-CNFs. The proposed sensor was successfully used to detect difenidol hydrochloride. Owing to the advantages of using three-dimensional carbon nanofibers, including a larger surface area, higher number of active sites, and faster electron transfer rate, the ECL sensor exhibited high sensitivity, a strong linear relationship between peak intensity and the concentration of difenidol hydrochloride, a low detection limit, and good reproducibility and repeatability under optimal conditions. Moreover, the modified electrodes exhibited good performance in terms of recovery. In conclusion, the proposed sensor has wide application prospects for the detection of difenidol hydrochloride.

Author Contributions: Conceptualization, L.L.; methodology, H.C. and Z.Z.; validation, Z.Z.; investigation, Z.Z.; writing-original draft preparation, Z.Z.; writing-review and editing, H.C. and Z.Z.; supervision, L.L.; resources, Y.L., W.H., J.F., T.T., and L.L.

Funding: This work is financially supported by the fund of the Key Laboratory for Processing of Sugar Resources of Guangxi Higher Education Institutes (2016TZYKF01), the fund of the Guangxi Key Laboratory of Green Processing of Sugar Resources (GXTZY201701), the Guangxi Natural Science Fund (Grant No.2016GXNSFBA 380073), the Young and Middle-aged Teachers Ability Promotion Project of Guangxi Autonomous Region (KY2016YB250), 
the Innovation Fund for Graduate Students of GuangXi (No. YCSW2019208), and the high levels of innovation team and excellence Scholars Program in colleges of GuangXi.

Conflicts of Interest: The authors declare no conflict of interest.

\section{References}

1. Bao, S.J.; Li, C.M.; Zang, J.F.; Cui, X.Q.; Qiao, Y.; Guo, J. New nanostructured $\mathrm{TiO}_{2}$ for direct electrochemistry and glucose sensor applications. Adv. Funct. Mater. 2008, 18, 591-599. [CrossRef]

2. Kline, S.; Laboratories, F. Diphenidol (Vontrol): A new antivertigo and antiemetic agent. Clin. Pharmacol. Ther. 1968, 9, 132-135.

3. Varoli, L.; Andreani, A.; Burnelli, S.; Granaiola, M.; Leoni, A.; Locatelli, A.; Morigi, R.; Rambaldi, M.; Bedini, A.; Fazio, N. Diphenidol-related diamines as novel muscarinic M receptor antagonists. Bioorg. Med. Chem. Lett. 2008, 18, 2972-2976. [CrossRef] [PubMed]

4. Murakami, K.; Inoue, N.; Fuchikami, C.; Tajima, K.; Hashino, A.; Fukui, H.; Noda, K.; Oka, M. Blockade of voltage-gated calcium channel Ca1.2 and $\alpha$-adrenoceptors increases vertebral artery blood flow induced by the antivertigo agent difenidol. Eur. J. Pharmacol. 2012, 689, 165-171. [CrossRef] [PubMed]

5. Li, J.; Jian, C.; Wang, L. Determination of Difenidol Hydrochloride by HPLC. Tianjin Pharm. 2009, 5, 4-7.

6. Guo, H.; Cui, X.; Yang, Z. Determination of Diphenidol Hydrochloride Tablets by HPLC. Chin. J. Pharm. 2000, 31, 166-167.

7. Luan, Y.J.; Dong, Y.; Wang, R.H.; Hou, X.P.; Wang, F.L.; Yu, Z.-S. LC-MS/MS determination of difenidol in human blood and application in law cases. Chin. J. Pharm. Anal. 2013, 33, 1137-1140.

8. Zhang, Y.; Lv, J.-R. Determination of Diphenidol Hydrochloride by Post-Chemiluminescence Reaction. J. Anal. Sci. 2008. [CrossRef]

9. Fu, P.; Zheng, Q. Determination of Diphenidol Hydrochloride Tablets and Its Content Uniformity by Anionic Surfactant Titration. Chin. Pharm. Aff. 2002, 16, 487-488.

10. Li, Y.-C.; Yi, G.-B.; Cai, Z.Y.; Chen, Z.G. Determination of the Difenidol Hydrochloride in Its Tablets by Microfluidic Chip. Guangzhou Chem. 2011. [CrossRef]

11. Afsharan, H.; Navaeipour, F.; Khalilzadeh, B.; Tajalli, H.; Mollabashi, M.; Ahar, M.J.; Rashidi, M.-R. Highly sensitive electrochemiluminescence detection of p53 protein using functionalized Ru-silica nanoporous@ gold nanocomposite. Biosens. Bioelectron. 2016, 80, 146-153. [CrossRef] [PubMed]

12. Yang, L.L.; Li, L.-J.; Luo, Y.; Zhang, R.R.; Cui, Y.; Cui, F.H.; Sun, K.; Li, Y.-Q. Preparation of Electrochemiluminescence Sensor by Immobilizing Tris(2,2'-bipyridine)ruthenium (II) on Gold Electrode with $\mathrm{NanoTiO}_{2}-\mathrm{ZnO} /$ Silica Sol/Conductive Adhesive Composite Film. Chin. J. Anal. Chem. 2015, 43, 547-552. [CrossRef]

13. Sun, J.; Gao, W.; Qi, L.; Song, Y.; Hui, P.; Liu, Z.; Xu, G. Detection of 1,3-dihydroxyacetone by tris(2,2'-bipyridine)ruthenium(II) electrochemiluminescence. Anal. Bioanal. Chem. 2018, 410, 1-6. [CrossRef] [PubMed]

14. Se Won, B.; Jeong-Wook, O.; Ik-Soo, S.; Sun, C.M.; Yang-Rae, K.; Hasuck, K.; Jong-In, H. Highly sensitive detection of DNA by electrogenerated chemiluminescence amplification using dendritic $\mathrm{Ru}(\mathrm{bpy})_{3}{ }^{2+}$-doped silica nanoparticles. Analyst 2010, 135, 603-607.

15. Wu, L.; Wang, J.; Ren, J.; Li, W.; Qu, X. Highly sensitive electrochemiluminescent cytosensing using carbon nanodot@ Ag hybrid material and graphene for dual signal amplification. Chem. Commun. 2013, 49, 5675-5677. [CrossRef] [PubMed]

16. Gao, Y.; Shao, J.; Liu, F. Determination of zinc ion based on electrochemiluminescence of $\mathrm{Ru}(\mathrm{phen})_{3}{ }^{2+}$ and phenanthroline. Sens. Actuators B Chem. 2016, 234, 380-385. [CrossRef]

17. Shao, H.; Jing, L.; Zhang, Q.; Hu, Y.; Sui, W.; Guo, Z. Ruthenium-based metal organic framework (Ru-MOF)-derived novel Faraday-cage electrochemiluminescence biosensor for ultrasensitive detection of miRNA-141. Sens. Actuators B Chem. 2018, 268, 39-46. [CrossRef]

18. Jian, Y.; Wang, H.; Lan, F.; Liang, L.; Ren, N.; Liu, H.; Ge, S.; Yu, J. Electrochemiluminescence based detection of microRNA by applying an amplification strategy and $\mathrm{Hg}$ (II)-triggered disassembly of a metal organic frameworks functionalized with ruthenium (II) tris (bipyridine). Microchim. Acta 2018, 185, 133. [CrossRef]

19. Jüttner, K.; Galla, U.; Schmieder, H. Electrochemical approaches to environmental problems in the process industry. Electrochim. Acta 2000, 45, 2575-2594. [CrossRef] 
20. Feng, D.; Wu, Y.; Tan, X.; Chen, Q.; Yan, J.; Min, L.; Ai, C.; Luo, Y.; Du, F.; Liu, S. Sensitive Detection of Melamine by an Electrochemiluminescence Sensor Based on Tris(bipyridine)ruthenium(II)-Functionalized Metal-Organic Frameworks. Sens. Actuators B Chem. 2018, 265, 378-386. [CrossRef]

21. Jie, L.; Wu, H.; Lu, L.; Sun, Z.; Yan, Z.; Feng, D.; Lei, Q. Porous graphene containing immobilized Ru(II) tris-bipyridyl for use in electrochemiluminescence sensing of tripropylamine. Microchim. Acta 2016, 183, 1211-1217.

22. Wu, Y.; Li, X.; Tan, X.; Feng, D.; Yan, J.; Hui, Z.; Xiao, C.; Huang, Z.; Han, H. A cyclic catalysis enhanced electrochemiluminescence aptasensor based $3 \mathrm{D}$ graphene/photocatalysts $\mathrm{Cu}_{2} \mathrm{O}-\mathrm{MWCNTs}$. Electrochim. Acta 2018, 282, 672-679. [CrossRef]

23. Thangavelu, K.; Raja, N.; Chen, S.M.; Liao, W.C. Nanomolar electrochemical detection of caffeic acid in fortified wine samples based on gold/palladium nanoparticles decorated graphene flakes (Au/PdNPs-GRF). J. Colloid Interface Sci. 2017, 501, 77-85. [CrossRef]

24. Li, P.; Li, L.; Xu, M.; Chen, Q.; He, Y. Enhanced photocatalytic property of $\mathrm{BiFeO}_{3} / \mathrm{N}$-doped graphene composites and mechanism insight. Appl. Surf. Sci. 2017, 396, 879-887. [CrossRef]

25. Ramaraj, S.; Mani, S.; Chen, S.-M.; Kokulnathan, T.; Lou, B.-S.; Ali, M.A.; Hatamleh, A.; Al-Hemaid, F.M. Synthesis and application of bismuth ferrite nanosheets supported functionalized carbon nanofiber for enhanced electrochemical detection of toxic organic compound in water samples. J. Colloid Interface Sci. 2018, 514, 59-69. [CrossRef]

26. Mani, S.; Ramaraj, S.; Chen, S.M.; Dinesh, B.; Chen, T.W. Two-dimensional metal chalcogenides analogous $\mathrm{NiSe}_{2}$ nanosheets and its efficient electrocatalytic performance towards glucose sensing. J. Colloid Interface Sci. 2017, 507, 378-385. [CrossRef]

27. Sakthivel, M.; Ramaraj, S.; Chen, S.-M.; Dinesh, B.; Ramasamy, H.V.; Lee, Y. Entrapment of bimetallic CoFeSe 2 nanosphere on functionalized carbon nanofiber for selective and sensitive electrochemical detection of caffeic acid in wine samples. Anal. Chim. Acta 2018, 1006, 22-32. [CrossRef]

28. Manček, B.; Kreft, S. Determination of cichoric acid content in dried press juice of purple coneflower (Echinacea purpurea) with capillary electrophoresis. Talanta 2005, 66, 1094-1097. [CrossRef]

29. Pan, W.; Liu, Y.; Huang, Y.; Yao, S. Determination of difenidol hydrochloride by capillary electrophoresis with electrochemiluminescence detection. J. Chromatogr. B Anal. Technol. Biomed. Life Sci. 2006, 831, 17-23. [CrossRef]

30. Pan, W.; Chen, X.; Guo, M.; Huang, Y.; Yao, S. A novel amperometric sensor for the detection of difenidol hydrochloride based on the modification of $\mathrm{Ru}(\mathrm{bpy})$ on a glassy carbon electrode. Talanta 2007, 73, 651-655. [CrossRef]

31. Promphet, N.; Rattanarat, P.; Rangkupan, R.; Chailapakul, O.; Rodthongkum, N. An electrochemical sensor based on graphene/polyaniline/polystyrene nanoporous fibers modified electrode for simultaneous determination of lead and cadmium. Sens. Actuators B Chem. 2015, 207, 526-534. [CrossRef]

32. Shen, H.; Qin, D.; Li, Y.; Li, S.; Chi, Y.; Yuan, Q.; Wagberg, T.; Hu, G. In situ Magnesiothermal Synthesis of Mesoporous MgO/OMC Composite for Sensitive Detection of Lead Ions. Electroanalysis 2016, 28, 2939-2946. [CrossRef]

33. Hu, G.; Nitze, F.; Sharifi, T.; Barzegar, H.R.; Wågberg, T. Self-assembled palladium nanocrystals on helical carbon nanofibers as enhanced electrocatalysts for electro-oxidation of small molecules. J. Mater. Chem. 2012, 22, 8541-8548. [CrossRef]

34. Sioda, R.E.; Frankowska, B. Voltammetric oxidation of naphthalene derivatives. J. Electroanal. Chem. 2008, 612, 147-150. [CrossRef]

35. Qie, L.; Chen, W.M.; Wang, Z.H.; Shao, Q.G.; Li, X.; Yuan, L.X.; Hu, X.L.; Zhang, W.X.; Huang, Y.H. Nitrogen-doped porous carbon nanofiber webs as anodes for lithium ion batteries with a superhigh capacity and rate capability. Adv. Mater. 2012, 24, 2047-2050. [CrossRef]

36. Qiu, Y.; Jie, Y.; Shi, T.; Zhou, X.; Bai, X.; Jian, Y.H. Nitrogen-doped ultrathin carbon nanofibers derived from electrospinning: Large-scale production, unique structure, and application as electrocatalysts for oxygen reduction. J. Power Sources 2011, 196, 9862-9867. [CrossRef]

37. Hu, G.; Nitze, F.; Gracia-Espino, E.; Ma, J.; Barzegar, H.R.; Sharifi, T.; Jia, X.; Shchukarev, A.; Lu, L.; Ma, C.; et al. Small palladium islands embedded in palladium-tungsten bimetallic nanoparticles form catalytic hotspots for oxygen reduction. Nat. Commun. 2014, 5, 5253. [CrossRef] 
38. Jeong, J.H.; Kim, B.H. Electrospun porous carbon nanofibers with controllable pore sizes by boron trioxide for electrochemical capacitor electrodes. J. Taiwan Inst. Chem. Eng. 2018, 84, 179-187. [CrossRef]

39. Si, W.; Zhou, J.; Zhang, S.; Li, S.; Xing, W.; Zhuo, S. Tunable N-doped or dual N, S-doped activated hydrothermal carbons derived from human hair and glucose for supercapacitor applications. Electrochim. Acta 2013, 107, 397-405. [CrossRef]

40. Wang, J.-G.; Liu, H.; Sun, H.; Hua, W.; Wang, H.; Liu, X.; Wei, B. One-pot synthesis of nitrogen-doped ordered mesoporous carbon spheres for high-rate and long-cycle life supercapacitors. Carbon 2018, 127, 85-92. [CrossRef]

41. Pei, F.; An, T.; Zang, J.; Zhao, X.; Fang, X.; Zheng, M.; Dong, Q.; Zheng, N. From Hollow Carbon Spheres to N-Doped Hollow Porous Carbon Bowls: Rational Design of Hollow Carbon Host for Li-S Batteries. Adv. Energy Mater. 2016. [CrossRef]

42. Li, Y.; Yang, L.; Li, L.; Luo, Y.; Cheng, H.; Huang, W. A novel electrochemiluminescence sensor for the determination of diphenidol based on a nano- $\mathrm{TiO}_{2} /$ silica sol/PVP/Ru (bpy) ${ }_{3}{ }^{2+}$ modified gold electrode. New J. Chem. 2015, 39, 2997-3003. [CrossRef]

43. Li, H.-J.; Han, S.; Hu, L.-Z.; Xu, G.-B. Progress in $\mathrm{Ru}(\mathrm{bpy})_{3}{ }^{2+}$ Electrogenerated Chemiluminescence. Chin. J. Anal. Chem. 2009, 37, 1557-1565. [CrossRef]

44. Gross, E.M.; Pastore, P.; Wightman, R.M. High-frequency electrochemiluminescent investigation of the reaction pathway between Tris(2,2'-bipyridyl) ruthenium (II) and tripropylamine using carbon fiber microelectrodes. J. Phys. Chem. B 2001, 105, 8732-8738. [CrossRef]

45. Yin, X.; Sha, B.; He, X. Electrochemiluminescence from tris (2,2'-bipyridyl) ruthenium (II) in the presence of aminocarboxylic acid co-reactants. Sci. China 2009, 52, 1394-1401. [CrossRef]

46. Zhang, J.-F.; Zhang, Z.-J.; Wang, Y.; Li, Y.-Y.; Li, R. Immobilized Ru (bpy) ${ }_{3}{ }^{2+}$ Electrochemiluminescence Coupled with Microdialysis Sampling for On-line Studying Drug-protein Interaction. Chin. J. Anal. Chem. 2012, 40, 730-734. [CrossRef]

47. Hao, W.; Huang, X.; Wan, L.; Gao, J.; Xue, H.; Li, R.K.Y.; Mai, Y.W. $\mathrm{TiO}_{2}$ nanoparticle decorated carbon nanofibers for removal of organic dyes. Colloids Surf. Physicochem. Eng. Asp. 2018, 549, 205-211.

48. Li, Y.-Q.; Luo, Y.; Li, L.-J.; Cheng, H.; Huang, W.-Y. Preparation and Application of Electrochemiluminescence Sensor by Immobilizing Tris(2,2'-bipyridine) ruthenium (II) on the Surface of Gold Electrode with Silica sol/Nano-Au/PVP/L-cysteine. Electrochemistry 2015, 83, 155-160. [CrossRef] 